Marquette University

e-Publications@Marquette

Psychology Faculty Research and Publications

Psychology Department

$11-1-1997$

\title{
The Progression of $\beta$-amyloid Deposition in the Frontal Cortex of the Aged Canine
}

Takao Satou

Kinki University

Brian J. Cummings

University of California - Irvine

Elizabeth Head

University of Toronto

Kristy A. Nielson

Marquette University, kristy.nielson@marquette.edu

Fletcher F. Hahn

Inhalation and Toxicology Research Institute

See next page for additional authors

Accepted version. Brain Research, Vol. 774, No. 1-2 (November 1997): 35-43. DOI. (C) 1997 Elsevier Science B.V. Used with permission.

Kristy Nielson was affiliated with the University of California - Irvine at time of publication. 


\section{Authors}

Takao Satou, Brian J. Cummings, Elizabeth Head, Kristy A. Nielson, Fletcher F. Hahn, Norton W. Milgram, Peter Velazquez, David H. Cribbs, Andrea J. Tenner, and Carl W. Cotman 


\title{
The Progression of $\beta$-amyloid Deposition In The Frontal Cortex Of The Aged Canine
}

\author{
Takao Satoua \\ Second Department of Pathology, \\ Kinki University School of Medicine, \\ Osaka, Japan \\ Brian J. Cummings
}

Laboratories for Molecular Neuroscience, McLean Hospital, Belmont, MA

Elizabeth Head

Department of Psychology, University of Toronto,

Toronto, Ont., Canada

Kristy A. Nielson

Institute for Brain Aging and Dementia, University of California, Irvine, CA

Fletcher F. Hahn

Inhalation and Toxicology Research Institute,

Albuquerque, NM

Norton W. Milgram

Department of Psychology, University of Toronto,

Toronto, Ont., Canada 


\title{
Peter Velazquez
}

Institute for Brain Aging and Dementia, University of California, Irvine, CA

David H. Cribbs

Institute for Brain Aging and Dementia, University of California, Irvine, CA

Andrea J. Tenner

Department of Molecular Biology and Biochemistry,

University of California,

Irvine, CA

Carl W. Cotman

Institute for Brain Aging and Dementia, University of California, Irvine, CA

\begin{abstract}
Brains from 41 aged canines ( $\geq 10$ years of age) were examined immunohistochemically to characterize the laminar distribution and agerelated progression of $\beta$-amyloid $(A \beta)$ in frontal cortex. We classified the $A \beta$ patterns into four distinct types. Type I was characterized by small, faint deposits of $A \beta$ in deep cortical layers. Type II consisted of diffuse deposits of $\mathrm{A} \beta$ mainly in layers $\mathrm{V}$ and $\mathrm{VI}$. Type III had both dense plaques in superficial layers, and diffuse deposits in deep layers. Finally, Type IV had solely dense plaques throughout all layers of cortex. We compared the $A \beta$ distribution pattern between the Old canines ( $10-15$ years, $n=22$ ) and the Very Old canines ( $>15$ years, $n=19$ ). The Old group primarily had negative staining, or Type I and Type II patterns of amyloid deposition (73\%). Conversely, the Very Old group had predominantly Types II, III and IV deposits (89.5\%), a difference that was significant $(P<0.05)$. We suggest that $A \beta$ deposition in canine frontal cortex is a progressive age-related process beginning with diffuse deposits in the deep cortical layers followed by the development of deposits in outer layers. In support of this hypothesis, the deeper layer diffuse plaques in the Very Old group of dogs also contain the largest proportion of $\beta$-amyloid with an isomerized aspartic acid residue at position 7 , indicating that these deposits had been present for some time. We also observed fiber-like $A \beta$ immunoreactivity within regions of diffuse $A \beta$ deposits. These fibers appeared to be degenerating neurites, which were negative for hyperphosphorylated tau. Therefore, these fibers may represent a very early
\end{abstract}

Brain Research, Vol 774, No. 1-2 (November 1997): pg. 35-43. DOI. This article is (C Elsevier and permission has been granted for this version to appear in e-Publications@Marquette. Elsevier does not grant permission for this article to be further copied/distributed or hosted elsewhere without the express permission from Elsevier. 
NOT THE PUBLISHED VERSION; this is the author's final, peer-reviewed manuscript. The published version may be accessed by following the link in the citation at the bottom of the page.

form of neuritic change that precede tau hyperphosphorylation or develop by an alternative pathway.

Keywords : Diffuse plaque, Plaque type, Isoaspartate $\beta$-amyloid, Aging, Alzheimer's, Animal model, Beagle dog lifespan

\section{I ntroduction}

The classical neuropathological hallmarks of Alzheimer's disease (AD) are the progressive accumulation of extracellular $\beta$-amyloid $(A \beta)$ within the parenchyma that form senile plaques, and intraneuronal cytoskeletal changes, which result in neurofibrillary tangles (NFTs). 3 It has become clear that different plaque subtypes are present within the brains of aged non-demented individuals and AD patients. These plaque subtypes appear to progress through specific, identifiable stages beginning with diffuse, non- $\beta$-pleated structures followed by primitive plaques and then neuritic plaques, which are thioflavine- and Congo-red-positive. ${ }^{7}$ Characterizing the development of these lesions and their relation to NFTs is critical to understanding the pathogenesis of AD. However, the study of these processes is exceptionally difficult using human tissue because they occur over the course of years.

Previously, we suggested that the aged canine is a model system particularly well-suited to the investigation of the initial stages of plaque formation. $\frac{6,8}{}$ The aged canine brain contains predominantly diffuse plaques. Furthermore, the incidence of plaque formation in the aged canine population is relatively high, without showing the classical feature of neurofibrillary tangle formation. Thus, this model may be useful for delineating the mechanisms involved in the initial stages of $\mathrm{A} \beta$ deposition and for studying the processes that promote plaque development into degenerative loci in the absence of tangles. $\frac{8}{\text { Such }}$ an animal model is necessary, since it is difficult to study early $A D$ pathology in the human brain due to the reserve capacity of the brain to absorb damage, $\underline{25}$ and the rarity of early-stage autopsy tissue.

In addition to early neuropathological changes being present in many aged canine brains, it has been reported that canines experience age-related cognitive dysfunction. Aged canines are impaired on a variety of tasks, including delayed non-matching-to-sample recognition learning and spatial learning. $\frac{15,22}{}$ Further, it has been reported that

Brain Research, Vol 774, No. 1-2 (November 1997): pg. 35-43. DOI. This article is @ Elsevier and permission has been granted for this version to appear in e-Publications@Marquette. Elsevier does not grant permission for this article to be further copied/distributed or hosted elsewhere without the express permission from Elsevier. 
various kinds of cognitive dysfunction in the aged canine correlate with the extent of $A \beta$ deposition in hippocampus and frontal cortex. $\underline{6}$ Accordingly, study of the aged canine brain may also aid in our understanding of the morphological and cognitive changes that occur in aging.

It is generally assumed that NFTs and $A \beta$ deposits in the human brain are not distributed randomly, but rather they have a characteristic regional and laminar pattern. $\frac{3}{}$ The research literature regarding the laminar distribution of senile plaques in $A D$ brain, however, is less than definitive. 20,24,27 For example, Braak et al. reported that neuritic plaques are predominantly found in layers II and III of occipital isocortex, ${ }^{4}$ while Lewis and co-workers reported that neuritic plaques are most numerous in layers III and IV of the visual and auditory cortices. $\underline{20}$ In fact, several investigators suggest that plaques are more common in the superficial cortical layers compared with deeper layers, $\frac{10,11,26}{}$ while others suggest just the opposite. $\frac{30,31}{10}$ The apparent variability in the laminar specificity of plaque distribution in $A D$ may be due in part to the variability in the disease stage of the cases examined in each study. As a result, characterizing the laminar distribution of $A \beta$ deposits with advancing age in the canine cortex could help to clarify the distribution and progression of $A \beta$ in $A D$ brain.

Therefore, in the present study we sought to characterize the distribution and progression of pathological changes in AD by use of an animal model of senile plaque formation. Specifically, we sought to clarify the laminar distribution of $A \beta$ within the frontal cortex of aged canines and to delineate the progression of $A \beta$ deposition over time using $A \beta$ immunocytochemistry and a large sample of aged canines. Because one consequence of amyloid deposition over a long period of time is the spontaneous isomerization of aspartic acid residues present at positions 1 and 7 of the $\beta$-amyloid peptide, $\underline{28}$ we also used an affinity purified antibody specific for the isomerized form of $\beta$-amyloid to further investigate a progression hypothesis. We chose frontal cortex because it has been suggested that the distribution of $A \beta$ is more consistent in frontal cortex than in the hippocampus, based on analyses of human brain. $\underline{25}$

Brain Research, Vol 774, No. 1-2 (November 1997): pg. 35-43. DOI. This article is @ Elsevier and permission has been granted for this version to appear in e-Publications@Marquette. Elsevier does not grant permission for this article to be further copied/distributed or hosted elsewhere without the express permission from Elsevier 


\section{Materials and methods}

Thirty-two of the 41 animals in the study were beagles from the Inhalation Toxicology Research Institute's (ITRI) animal colony in Albuquerque, New Mexico. There were 27 females and 5 males. The age of these dogs ranged from 10.4 to 17.7 years at death (see Table 1 ). These dogs were part of a study designed to evaluate the health effects of the monoamine oxidase inhibitor l-deprenyl on young adult and aged beagles. Thus, they were treated with I-deprenyl ( 1 $\mathrm{mg} / \mathrm{kg} /$ day) or placebo once a day for approximately 2 years 10 months. The time between cessation of treatment varied from 0 days to 101 days, depending on the cause of death (i.e. unplanned death, euthanasia due to disease, or planned sacrifice). The dogs were housed in kennel buildings with indoor and outdoor runs. They were fed a dry kibble (Wayne Mini Lab Dog Diet 8759, Teklad Laboratory Diets, Madison, WI) once a day over their life span.

Table 1. Descriptive data (mean \pm S.E.M., frequencies) on the groups of canines

\begin{tabular}{|c|c|c|c|c|}
\hline Group & Sex & Age (years) & Breed $^{\mathbf{b}}$ & Treatmenta \\
\hline Total (41) & $6 \mathrm{M}, 35 \mathrm{~F}$ & $14.2 \pm 0.4$ & $32 \mathrm{~B}_{1}, 5 \mathrm{~B}_{2}, 4 \mathrm{P}$ & 19 yes, 22 no \\
\hline Old: $10-15$ years (22) & $2 \mathrm{M}, 20 \mathrm{~F}$ & $12.5 \pm 0.4$ & $13 \mathrm{~B}_{1}, 5 \mathrm{~B}_{2}, 4 \mathrm{P}$ & 7 yes, 15 no \\
\hline Very Old: >15 years (19) & $4 \mathrm{M}, 15 \mathrm{~F}$ & $16.2 \pm 0.2$ & $19 \mathrm{~B}_{1}, 0 \mathrm{~B}_{2}, 0 \mathrm{P}$ & 12 yes, 7 no \\
\hline
\end{tabular}

There were also five beagles born and raised at Marshall Farms in NY and four pound mongrels included in the study (Table 1). Two were male and seven (including all five beagles) were female, with ages ranging from 10.0 to 12.3 years. The age of the four pound dogs was based on available records and dentition.

The ITRI beagles were born and raised in the ITRI dog colony. The breeding program was a random, generation type system designed to maintain a gene pool as broad as possible. The members of each breeding generation were selected randomly from the available population, with restrictions placed only on sibling and half-sibling matings, and exclusion of dogs with EEG tracings suggestive of epilepsy. $\underline{2}$ 
NOT THE PUBLISHED VERSION; this is the author's final, peer-reviewed manuscript. The published version may be accessed by following the link in the citation at the bottom of the page.

The dogs were observed daily by the animal technicians and were treated for all detected injuries and illnesses by the veterinary

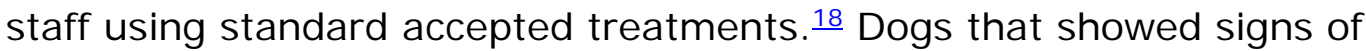
pain or anxiety that could not be controlled with medication were euthanized. Some of the dogs were euthanized as a planned schedule. All dogs that died or were euthanized were necropsied as soon as possible and all major organs were examined. Major organs and all lesions found were sampled for histopathology. A cause of death and other significant diseases for each dog were determined from the clinical records and pathology information.

In addition to the dogs included in this study, there were 398 control dogs that have been cared for in the colony for their entire life span. These dogs were used to estimate the life span of the laboratory beagle. The survival of this population was determined using a lifetable method of analysis. The BMDP1 L Life Tables and Survival Functions statistical software package was used for this analysis. The cumulative survival is shown in Fig. 1. The median survival time was 13.7 years for the males and $\mathbf{1 3 . 6}$ years for the females. The survival times were not significantly different as demonstrated by the log-rank test.

Brain Research, Vol 774, No. 1-2 (November 1997): pg. 35-43. DOI. This article is (C) Elsevier and permission has been granted for this version to appear in e-Publications@Marquette. Elsevier does not grant permission for this article to be further copied/distributed or hosted elsewhere without the express permission from Elsevier. 


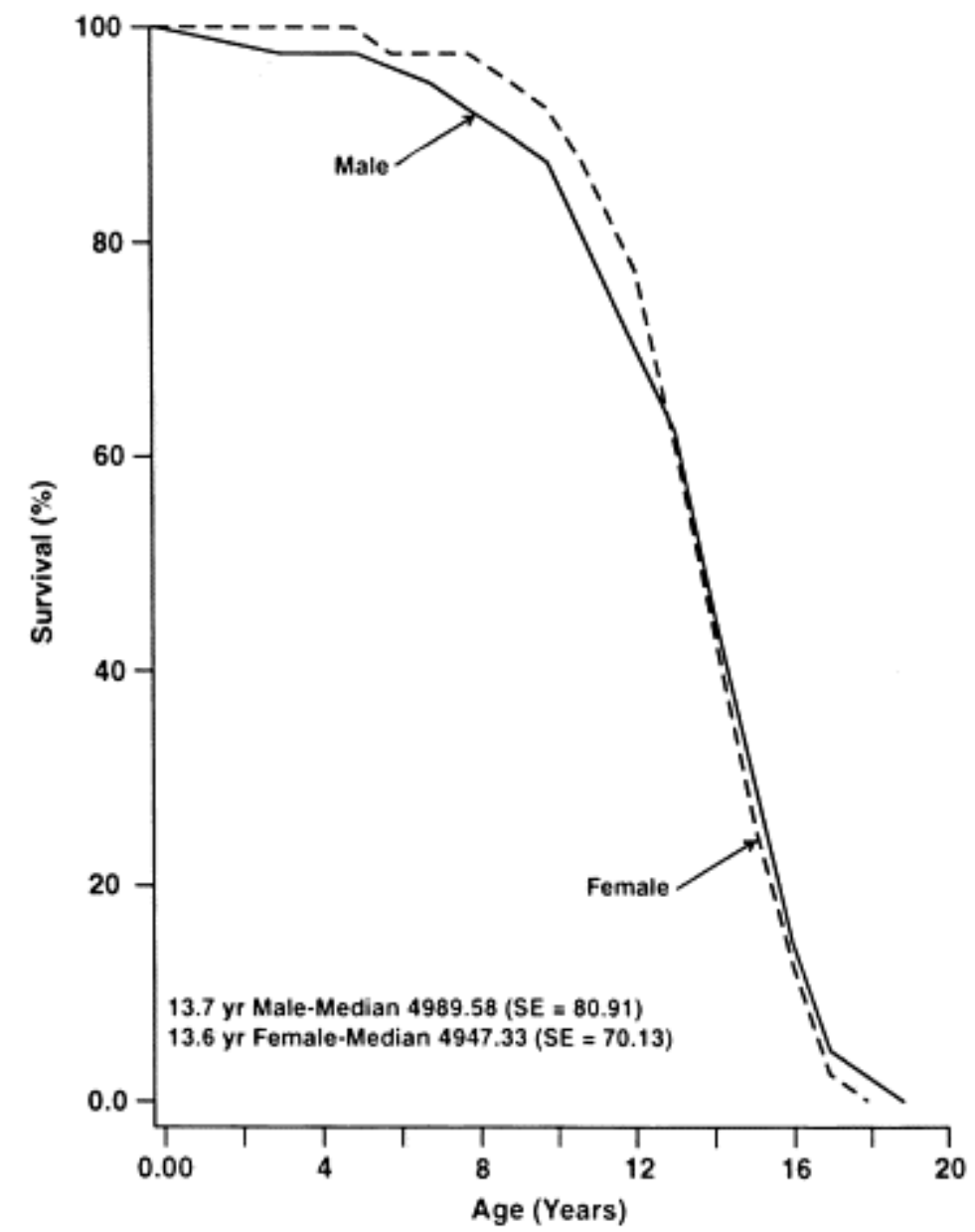

Fig. 1. The cumulative survival curves for male and female control dogs $(n=398)$ at the Inhalation Toxicology Research Institute. The median survival times of 13.7 years for males and 13.6 years for females were not significantly different (log-rank test).

Coronal brain sections ( $1 \mathrm{~cm}$ thick) were fixed in $4 \%$ paraformaldehyde for 2 days and held in $10 \%$ neutral buffered formalin at post-mortem. Dorsolateral frontal cortex was sectioned free-floating $(50 \mu \mathrm{m})$ using a Vibratome. The sections were pretreated with $70 \%$ formic acid for 5 min and incubated with an affinity purified $\beta$-amyloid antibody (A $\beta 42,1: 1000)$ or an affinity purified antibody directed against isomerized $\beta$-amyloid (isoAsp7, 1:1050) using standard immune-histochemical procedures. ${ }^{9} A \beta 42$ is a rabbit polyclonal antibody against synthetic $A \beta_{1-42}$ amyloid peptide. It preferentially recognizes full-length $A \beta$ on Western blots and does not cross-react with native amyloid precursor protein (APP) in tissue or on Western blots. $\frac{34}{}$ I soAsp is a rabbit polyclonal antibody raised against synthetic $A \beta_{1-15}$ with isoaspartic acid substituted for the aspartic acid 
at position 7. $\frac{14}{} A$ 16-amino-acid peptide of $A \beta_{1-15}$ was synthesized ( $C$. Glabe, $\mathrm{UCI}$ ) containing isoAsp at residue 7 and a cysteine at residue 16 (the carboxy terminus). $500 \mu \mathrm{l}$ at $2 \mathrm{mg} / \mathrm{ml}(0.976 \mu \mathrm{l})$ of this peptide was mixed with $200 \mu \mathrm{l}$ reconstituted Pierce Maleimide Activated Keyhole Limpet Hemocyanin (KLH) (product \#77106) at $10 \mathrm{mg} / \mathrm{ml}$ ( $0.7 \mu \mathrm{mol}$ maleimide groups) and allowed to react for $2 \mathrm{~h}$ at room temperature. Aliquots of this immunogen (isoAsp7-KLH) were then frozen and stored at $-70^{\circ} \mathrm{C}$. For immunization, $375 \mu \mathrm{l}$ isoAsp7-KLH was emulsified with $375 \mu$ l Freund's complete adjuvant (FCA) and injected (S.c.) into a New Zealand white rabbit. The rabbit was boosted with 150-200 $\mu$ l (s.c.) twice at 2-week intervals with equal volumes of immunogen emulsified with Freund's incomplete adjuvant (FIA). One week after the first boost and 1 and 2 weeks after the second boost the rabbit was bled, screened for the presence of isoAsp7-specific antibodies, and rabbit IgG from three pooled bleeds was purified from serum using the octanoic acid/ammonium sulfate method. $A \beta$ antibodies not specific for isoAsp7 were depleted from rabbit IgG using non-isomerized $A \beta_{1-40}$ conjugated to Reacti-Gel Column (Pierce product \#20259) three times. Antibodies specific for $A \beta$ IsoAsp7 were then affinity purified from the rabbit IgG using the antigenic peptide containing isoAsp7 conjugated to Sulfolink coupling gel (Pierce product \#20401). The eluted antibodies were then rerun over non-isomerized $A \beta 1-40$ Recti-Gel Column to remove any remaining antibodies not specific for $A \beta$ isoAsp7. The absence of $A \beta 1-40$ cross-reactivity in the affinity purified anti-isoAsp7 antibodies was verified by an indirect detection ELISA.

After immunostaining, tissue sections were lightly Nissl counterstained to identify the cell layers. After dehydration in a graded series of alcohols and penetration with Histoclear (National Diagnostics, Atlanta, GA), sections were coverslipped with DePex (BDH Laboratory Supplies, Poole, UK). All sections were observed by light microscopy. In control experiments, we omitted the primary antibody or used normal rabbit serum instead of the primary antibody as negative controls. These tests resulted in no staining in the tissue sections.

To confirm degenerative nerve fibers, we double-labeled for A 342 and abnormally phosphorylated tau via PHF-1 (monoclonal antibody raised in mouse and kindly provided by Dr. S. Greenberg;

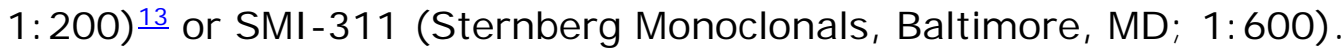

Brain Research, Vol 774, No. 1-2 (November 1997): pg. 35-43. DOI. This article is @ Elsevier and permission has been granted for this version to appear in e-Publications@Marquette. Elsevier does not grant permission for this article to be further copied/distributed or hosted elsewhere without the express permission from Elsevier. 
Following $A \beta 42$ staining and reaction with diaminobenzidine (DAB), the tissues were incubated in a second primary antibody overnight and then rinsed and incubated for $1.5 \mathrm{~h}$ in CY3-conjugated anti-mouse immunoglobulin G (IgG) (Jackson ImmunoResearch, 1:200). Sections were then washed in phosphate-buffered saline and mounted on gelatin-subbed slides with Vectashield (Vector Labs, CA).

\section{Results}

We observed $A \beta$ deposition in nearly all of the aged canines examined ( $95 \%$ ). While examining $A \beta$ deposition in more than 100 animals over the past few years, we have noted that there appear to be several distinct patterns of $A \beta$ deposition with possible intermediate stages. In some animals, large $A \beta$-immunopositive plaques are present within the superficial layers of cortex. In other animals, a diffuse cloud of $A \beta$ deposition appears to have spread throughout the deep layers of cortex. This diffuse zone of $A \beta$ often measures several millimeters. Based on these observations, we classified the morphological patterns of $A \beta$ deposition observed in the aged canine brains in the present study into four subtypes. These subtypes are depicted in diagrammatic form in Fig. 2 and shown photographically in Fig. 3.

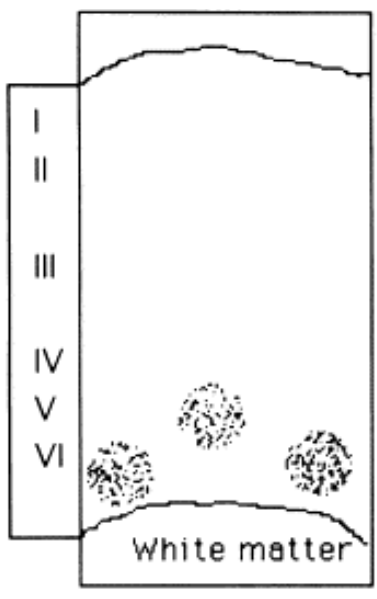

Type I

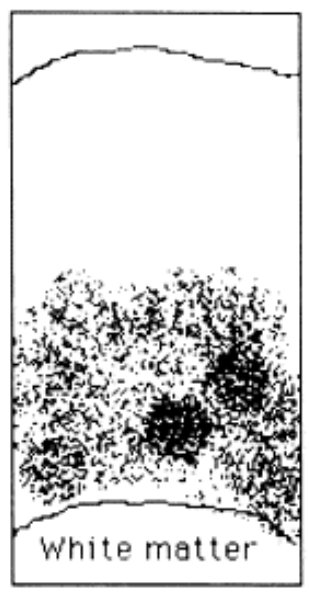

Type II

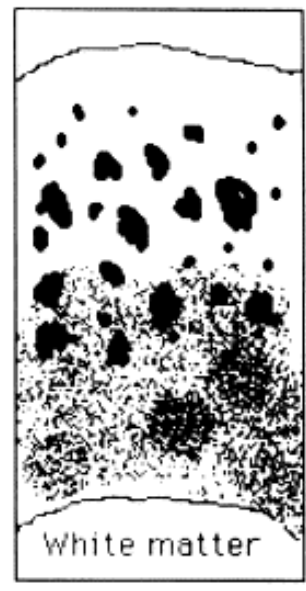

Type III

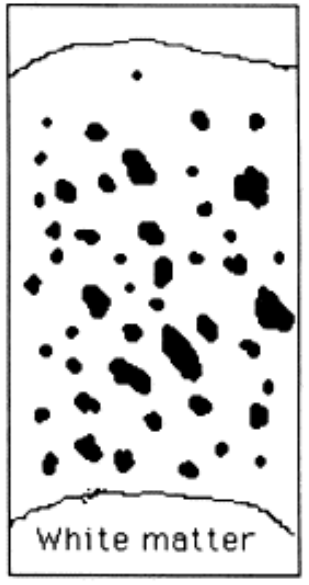

Type IV

Fig. 2. Diagrammatic representation of the predominant patterns of $A \beta$ deposition found in the frontal cortex of aged canines. The relative regions of each cortical layer are indicated in the left margin. 

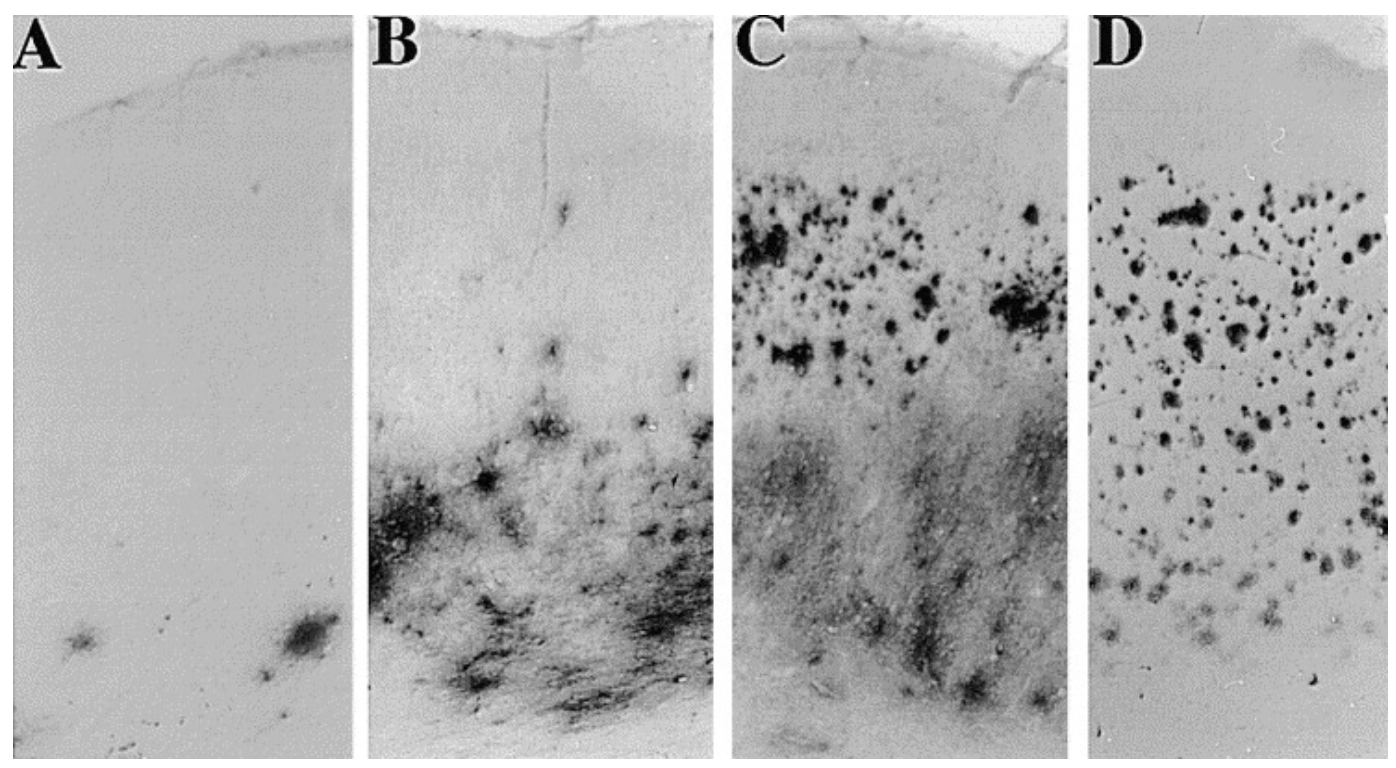

Fig. 3. Representative photomicrographs $(\times 10)$ of each of the four patterns of $A \beta$ deposition found in the frontal cortex of aged canines. Type I is shown in A, type II in B, type III in C and type IV in D. Two of the 41 canines exhibited no A $\beta$ immunoreactivity. The remaining 39 animals were classified according to predominant $\mathrm{A} \beta$ pattern while blind to the experimental variables (e.g. age, sex, pharmacological treatment or breed).

\subsection{Type I}

$A \beta$ deposition was light in density, small in size (less than 180 $\mu \mathrm{m}$ in diameter), and round in shape. These deposits were primarily restricted to layers $\mathrm{V}$ and $\mathrm{VI}$ and had obscure boundaries. These $\mathrm{A} \beta$ positive plaques were usually isolated and few in number (Fig. 2, Fig. $\underline{3}$ ). The Type I pattern also contained fine fiber-like $A \beta$ deposits around neurons (see Fig. 4). 

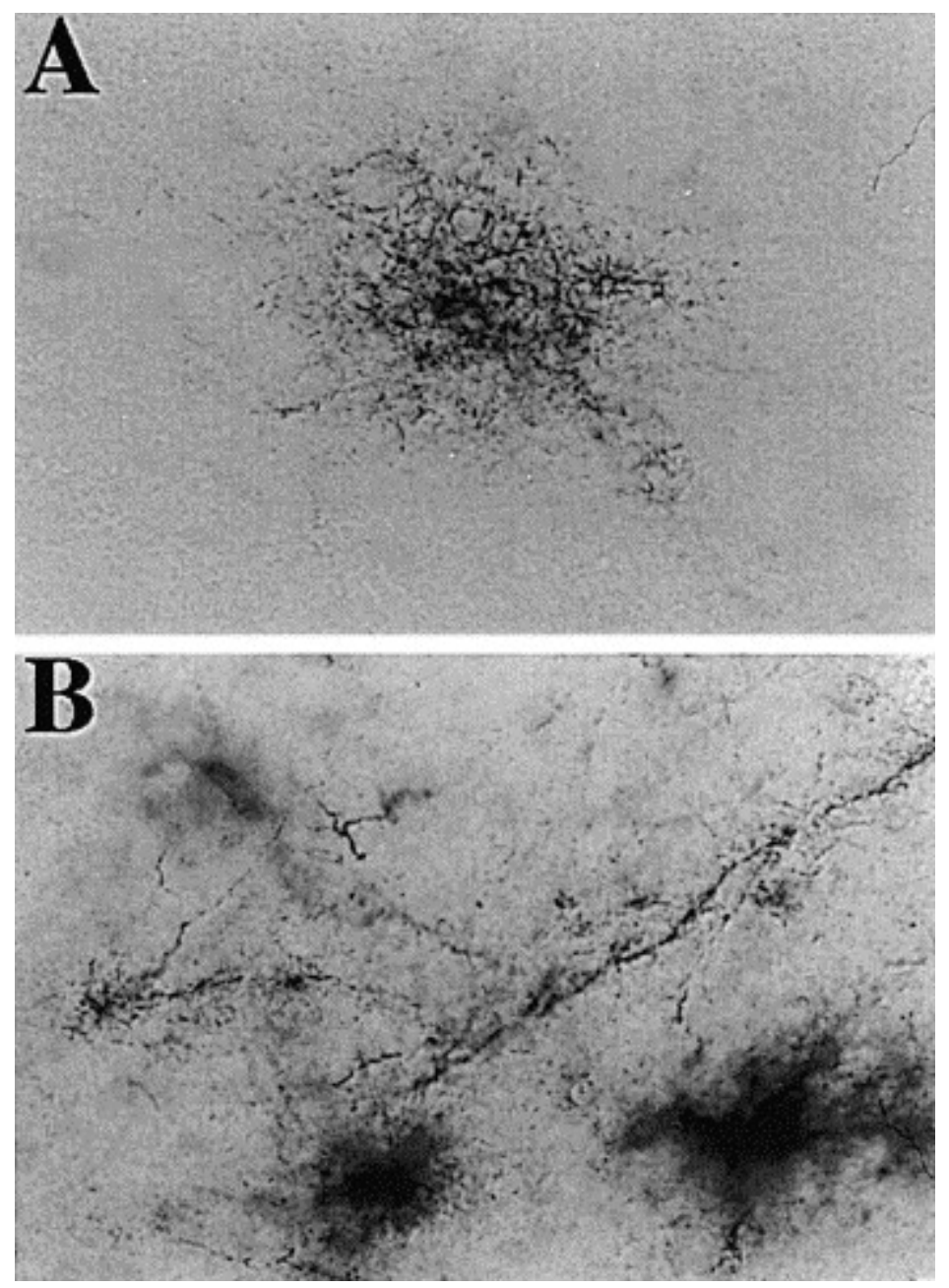

Fig. 4. $A$ : photomicrograph $(\times 100)$ showing fine fiber-like $A \beta$ immunoreactivity found in Type I $A \beta$ deposition in the deep layers (V, VI) of canine frontal cortex. B: photomicrograph (100x) of $A \beta$-immunopositive tortuous fiber-like structures within the diffuse $A ß$-immunoreactive zone of Type II $A \beta$ deposition in canine frontal cortex. These fibers were PHF-I negative.

\subsection{Type II}

$A \beta$ deposition was diffuse, cloud-like, and located primarily within the deep layers of cortex ( $V$ and $V I$ ). These $A \beta$ deposits typically had obscure boundaries and a conspicuous tendency to fuse together. The deposits usually extended horizontally for several millimeters, but sometimes they also extended superficially to layers IV and III, and occasionally even to layer II. A $\beta$-Immunopositive tortuous fiber-like structures were also observed within the diffuse $A \beta$-immunoreactive zone, especially in the deeper layers (see Figs. 3 and 4 ). 
NOT THE PUBLISHED VERSION; this is the author's final, peer-reviewed manuscript. The published version may be accessed by following the link in the citation at the bottom of the page.

\subsection{Type III}

$\mathrm{A} \beta$ deposition consisted of dense, round $A \beta$-positive plaques similar in morphological appearance to human senile plaques. They were usually less than $120 \mu \mathrm{m}$ in diameter, but some exceeded 200 $\mu \mathrm{m}$. This type of $A \beta$ deposit displayed fairly distinct superficial boundaries within layers I through III. Type III deposition was also accompanied by a deeper cloud-like diffuse $A \beta$ deposit comparable to that seen in Type II A $\beta$ deposition (see Fig. 2, Fig. 3).

\subsection{Type IV}

$A \beta$ deposition consisted of dense, round $A \beta$ positive plaques throughout all layers of frontal cortex, rather than being restricted to layers I-III as in Type III. Type IV deposition, which was more rare than Type III, also lacked the diffuse $A \beta$ 'cloud' in the deep cortical layers seen in Type III (see Fig. 2, Fig. 3).

While blinded to the experimental conditions, the predominant type of $A \beta$ deposition present was classified for each animal. We then compared the distribution of $A \beta$ subtypes between the Old group, which was composed of 10 - to 15 -year old canines $(n=22)$, and the Very Old group, which was composed of canines older than 15 years $(n=19)$.

Nearly $10 \%$ of the animals in the Old group displayed no $A \beta$ immunoreactivity, with $A \beta$ Types I and II most commonly found in this group. Indeed, these three $A \beta$ patterns (negative, I and II) characterized $73 \%$ of the canines between the ages of 10 and 15 years (see Table 2). Conversely, all of the Very Old canines exhibited some A $\beta$ deposition. Types II, III and IV characterized $89.5 \%$ of the Very Old group. Graphical representation revealed that there is a shift in the deposition pattern to the right with advancing age, such that Types I and II in the 10-15-year-old dogs give way to Types III and IV in the dogs older than 15 years (see Fig. 5). Comparison of the Old and Very Old groups by Mann-Whitney $U$ analysis demonstrated a statistically significant difference between the deposition patterns $(U=134.5$, $z=-2.04, P<0.05)$. There were no significant effects of tissue source, sex, breed, or monoamine oxidase inhibitor treatment on $A \beta$ type. To

Brain Research, Vol 774, No. 1-2 (November 1997): pg. 35-43. DOI. This article is @ Elsevier and permission has been granted for this version to appear in e-Publications@Marquette. Elsevier does not grant permission for this article to be further copied/distributed or hosted elsewhere without the express permission from Elsevier. 
validate these results, $A \beta$ type and age were submitted to simple and multiple regression models. Age was a significant predictor of $A \beta$ deposition type $(r=0.43, P=0.005)$, while breed, sex, and monoamine oxidase inhibitor treatment were not significant predictors.

Table 2. Proportion of canine cases by age group exhibiting each of the patterns of $A \beta$ deposition

Dog age group No $A$

$10-15$ years $(22)$

$9.1 \%(2)$

Type

Type II

Type III

Type IV

$>15$ years (19)

$0.0 \%(0) \quad 10.5 \%(2)$

$40.9 \%(9)$

$22.7 \%(5)$

$4.6 \%(1)$

Raw numbers of cases are in parentheses.

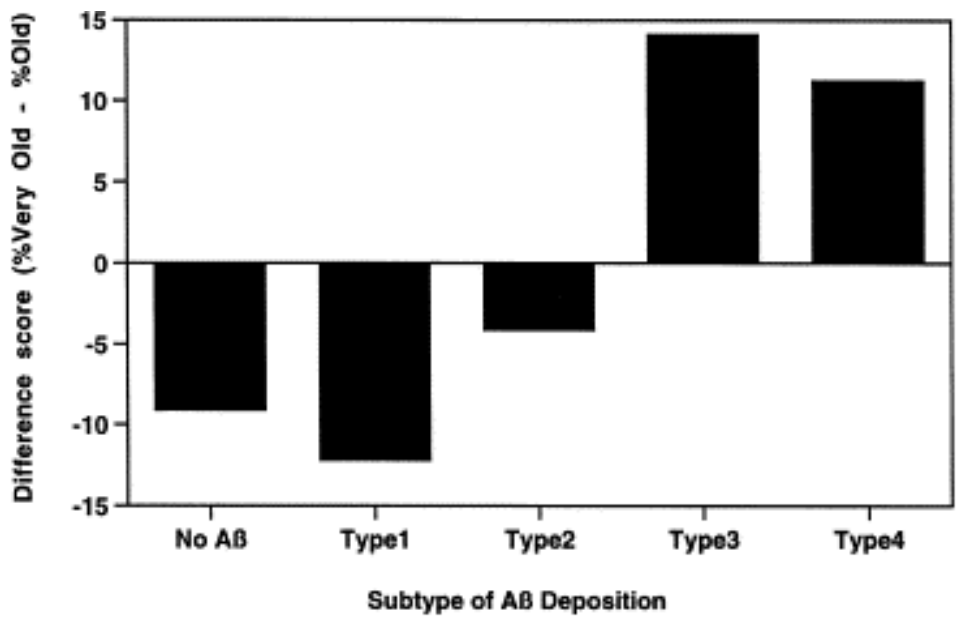

Fig. 5. Histogram depicting the change in proportion of $A \beta$ deposition type between canines in the Old group (10-15 years) and the Very Old group ( $>15$ years). There was a clear shift to the right, toward Types III and IV, in the Very Old group.

If, as suggested by our observations, deeper layer plaques are deposited before more superficial layers, then a marker of amyloid 'age' should be more prevalent in the deeper layers. $\beta$-Amyloid contains several aspartate residues that, over time, will isomerize to isoaspartate and could be detected with an antibody specific to $\beta$ amyloid containing isoaspartate. $\underline{28}$ Accordingly, an antibody was raised to $\beta$-amyloid where an isoaspartate was substituted for aspartate at position 7. The affinity purified antibody was found to be specific (see Section 2) and was used to determine if the presence of isoAsp7 $\beta$ amyloid was preferentially distributed to specific layers. Only a proportion of plaques labeled with $\beta$-amyloid are also labeled with isoAsp7. In Type III and IV patterns of $\beta$-amyloid deposition, deep layer plaques, but few superficial layer plaques were positive for isoAsp7 (Fig. 6). This, along with the data on age-related changes, 
NOT THE PUBLISHED VERSION; this is the author's final, peer-reviewed manuscript. The published version may be accessed by following the link in the citation at the bottom of the page.

supports the hypothesis that there is a sequence of plaque deposition in the canine frontal cortex which can be visualized as distinct patterns or 'Types'.
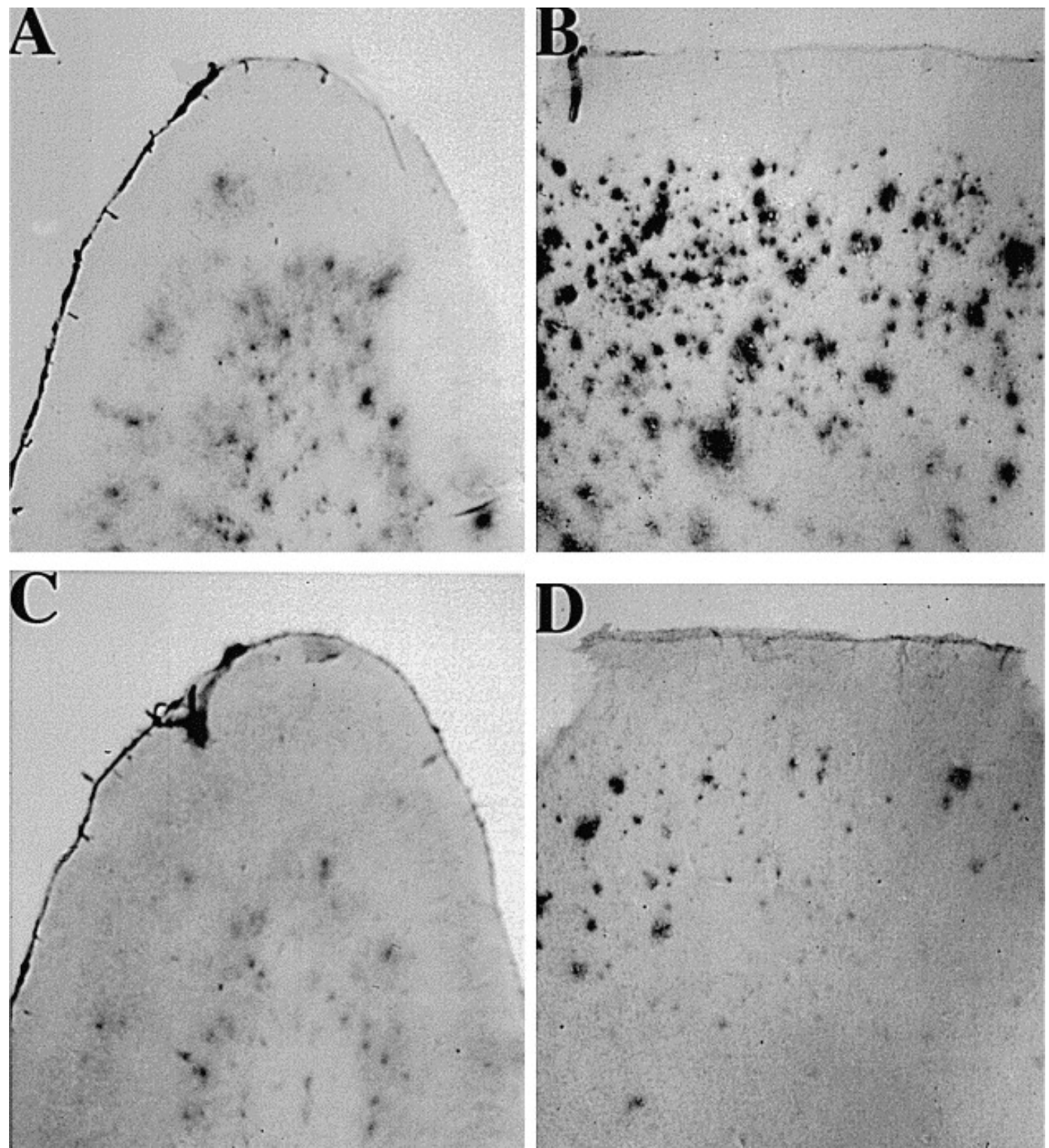

Fig. 6. Representative photomicrographs showing that deeper layer diffuse plaques containing A $\beta$ typical of Type III (A) and Type IV (B) also contain isoAsp7 $\beta$-amyloid (C and D).

The staining for PHF- 1 was completely negative for cell bodies and fibers of neurons on the stained sections. SMI-311 was positive primarily in cell bodies of neurons but did not delineate $A \beta$ immunopositive fibers. 
NOT THE PUBLISHED VERSION; this is the author's final, peer-reviewed manuscript. The published version may be accessed by following the link in the citation at the bottom of the page.

\section{Discussion}

We immunohistochemically examined frontal cortex tissue from 41 canines who were 10 or more years of age to characterize $A \beta$ deposits and the differences in their distribution with age. We identified four distinct patterns of $A \beta$ deposition: rare, punctate deposits in the deep layers; large, deep, cloud-like deposits; and dense, round plaques traversing all cortical layers. There was a clear change in the pattern of $A \beta$ deposition with advancing age, which did not appear to relate to the source, sex, or pharmacological history of the animals. $A \beta$ deposition within the Old animals ( $10-15$ years old) consisted predominantly of small deposits within the deep cortical layers and diffuse cloud-like deposits, also predominantly restricted to deeper layers (i.e. Types I and II). Within this group, negative staining, Type I, and Type II patterns accounted for $73 \%$ of the cases, with Type II being the most prominent pattern (41\%). In contrast, the Very Old group ( $>15$ years old) exhibited Type III and IV patterns much more frequently. In fact, Types II, III and IV made up $90 \%$ of $\mathrm{A} \beta$ deposition in the Very Old cases, with Type III occurring as frequently as Type II ( $37 \%$ each).

Thus, with increasing age, there appeared to be a shift towards larger, denser $A \beta$ deposits in the form of senile plaques, as well as greater deposition of $A \beta$ in the superficial layers. Based on these observations, we hypothesize that the earliest deposition of $A \beta$ occurs within the deep layers of frontal cortex (layers V and VI) in the canine. Over time, diffuse cloud-like extensions of $A \beta$ also form in the deepest layers of cortex. Later, denser plaque-like deposits of $A \beta$ form in the more superficial layers of cortex (i.e. II and III), and these deposits grow in size. The presence of deep layer diffuse plaques positive for isomerized aspartic acid residues also supports a progression hypothesis. Importantly, the median life expectancy of the canine population examined is just under 14 years (see Fig. 1) and yet $A \beta$ deposition was commonly observed much earlier. Therefore, it appears that $A \beta$ deposition begins in late middle age, rather than in the latest stages of life.

We also observed fiber-like $A \beta$ immunostaining within the deep cortical layers. We have previously described these fibers ${ }^{6}$ as

Brain Research, Vol 774, No. 1-2 (November 1997): pg. 35-43. DOI. This article is @ Elsevier and permission has been granted for this version to appear in e-Publications@Marquette. Elsevier does not grant permission for this article to be further copied/distributed or hosted elsewhere without the express permission from Elsevier. 
neurofilament-positive and $A \beta$-positive fibers; they are similar in morphological appearance to neuropil threads, which are nearly always observed in the AD brain. ${ }^{4}$ Braak et al. have indicated that neuropil threads may densely fill a layer without the presence of NFTs (e.g. layer $\mathrm{V}$ of striate cortex). Since these neuropil threads are important components of AD-related pathology, efforts to elucidate the conditions responsible for their development and pattern of distribution are valuable. $\stackrel{4}{ }$ In the canine brain, however, NFT changes have not been observed. $\underline{6}$ Similarly, we did not detect PHF- 1 or SMI- 311 immunoreactivity associated with $A \beta$-positive fibers in the present study. We suspect that the canine brain exhibits very early phosphorylation changes in nerve fibers, which cannot be detected with the antibodies that show tau pathology in AD brain. Alternatively, age-associated nerve fiber degeneration in the canine brain may be caused by a mechanism other than hyperphosphorylation of tau. For example, Migheli et al. argue that ubiquitin-positive fibers are present within the aged canine brain. $\underline{21}$

While it is clear that extensive $A \beta$ deposition commonly occurs in the aged canine, the source of the $A \beta$ found within the neuropil remains unknown. In a number of model systems, it has been confirmed that $A \beta$ is secreted by neurons. $\frac{1,5}{1}$ Indeed, we often observe $A \beta$-filled neurons in the canine brain. $\frac{6,8}{\mathrm{In}}$ addition, $A \beta$ is detectable in human cerebrospinal fluid. $12,29,32,33$ Therefore, there is likely to be an evacuation mechanism for $A \beta$ from the parenchyma to the ventricular system. Furthermore, it has been reported that APP is produced in the cell body of neurons and is carried by anterograde fast axonal flow to nerve endings and, at sites of amyloid deposition, is aberrantly processed into $A \beta . \underline{19}$ This raises the possibility that either overproduction of APP and A $\beta$, abnormal axonal flow, or abnormal clearance of $A \beta$ are the cause of $A \beta$ deposition in the aged brain. It is also possible that more than one of these factors contributes to the problem.

Our observations of fiber-like $A \beta$ staining within deep layers of frontal cortex and the diffuse deposits surrounding them in the neuropil (Fig. 4) are consistent with the suggestion that $A \beta$ deposition is initiated at the nerve terminal. $\underline{23}$ These $A \beta$-immunopositive fibers may therefore be an expression of early $A \beta$ deposition originating in corticocortical projections $\underline{16}$ from layers II and III to deeper layers.

Brain Research, Vol 774, No. 1-2 (November 1997): pg. 35-43. DOI. This article is @ Elsevier and permission has been granted for this version to appear in e-Publications@Marquette. Elsevier does not grant permission for this article to be further copied/distributed or hosted elsewhere without the express permission from Elsevier. 
NOT THE PUBLISHED VERSION; this is the author's final, peer-reviewed manuscript. The published version may be accessed by following the link in the citation at the bottom of the page.

Later in time, $\mathrm{A} \beta$ deposits may form around the cell bodies of these projecting neurons. Indeed, we observed that the dense round-shaped $\mathrm{A} \beta$ deposits in the Type III pattern were localized around the neurons in layers II and III. These results have important implications for the relationship between $A \beta$ and nerve fiber degeneration in the aged canine. For example, it has been reported that axonal degeneration promotes abnormal accumulation of $A \beta$ in the ascending gracile tract of the gracile axonal dystrophy mouse. $\underline{17}$

There were remarkable similarities between the late-stage $A \beta$ deposition patterns of aged canines and that in AD brain. First, Type III and IV canine plaques resembled the human senile plaques observed in AD brain, although other studies have shown that canine plaques did not exhibit $\beta$-pleated structure and they were larger than

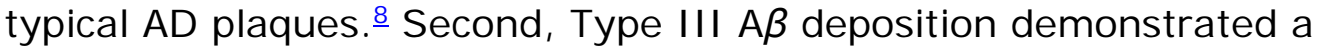
laminar distribution, primarily in layers II and III. On the other hand, Type IV A $\beta$ deposition, where canine plaques appeared even more similar in shape to human senile plaques, was scattered across all layers with no laminar specificity. This pattern was comparable to the irregular laminar distribution of plaques in AD brain. 4

Our observations in the canine brain suggest that the process of $\mathrm{A} \beta$ deposition is multiphasic, exhibiting different morphological and laminar characteristics over time. Thus, the laminar distribution of senile plaques may become obscured in human brain as AD reaches advanced stages. Moreover, it has been reported that as the severity of dementia increases, the density of mature plaques generally increases, but that of primitive plaques decreases, such that there tends to be an overall decrease in total plaque density. $\underline{25}$ This makes analysis of the distribution of $A \beta$ deposition in $A D$ brain complex, especially using general histological staining methods. Therefore, the interpretation of results from previous reports of $A \beta$ distribution in $A D$ brain may have been obscured by the inclusion of observations from patients at several different stages of AD pathology.

In this study, we found diffuse $A \beta$ deposits in the deep layers of frontal cortex. This morphology has not been reported in aged human or AD brain. This phenomenon may be a very early event in the deposition of $A \beta$ in frontal cortex, making it difficult to observe in human brain. Alternatively, it may be a pattern specific to the aged

Brain Research, Vol 774, No. 1-2 (November 1997): pg. 35-43. DOI. This article is @ Elsevier and permission has been granted for this version to appear in e-Publications@Marquette. Elsevier does not grant permission for this article to be further copied/distributed or hosted elsewhere without the express permission from Elsevier. 
canine. This issue remains to be clarified. As the aged canine model of $A \beta$ deposition is further characterized and refined, it will certainly be important for testing hypotheses about $A \beta$ deposition and plaque formation in human aging and AD.

\section{Acknowledgements}

We gratefully acknowledge the editorial assistance of Andrea Walencewicz Wasserman in manuscript preparation. This project was supported by Grants AG12694 (C.W.C., B.J.C., N.W.M.), AG00538 (C.W.C.), AG05716 (K.A.N.), and NIH N535144 (D.H.C.).

\section{References}

IW. Araki, T. Kunishita, K. Takahashi, S. I keda, T. Tabira. Demonstration of amyloid $\beta$-protein secretion in a mouse neuronal cell line. Neurosci. Lett., 167 (1994), pp. 125-127 [published erratum appears in Neurosci. Lett., 171(1-2) (1994) 225]

2S.W. Bielfelt, A.J. Wilson, H.C. Redman, R.O. McClellan, L.S. Rosenblatt. A breeding program for the establishment and maintenance of a stable gene pool in a beagle dog colony to be utilized for long-term experiments. Am. J. Vet. Res., 30 (1969), pp. 2221-2229

$3 \mathrm{H}$. Braak, E. Braak. Neuropathological staging of Alzheimer-related changes. Acta Neuropathol. (Berl.), 82 (1991), pp. 239-259

4H. Braak, E. Braak, P. Kalus. Alzheimer's disease: areal and laminar pathology in the occipital isocortex. Acta Neuropathol. (Berl.), 77 (1989), pp. 494-506

5]. Busciglio, D.H. Gabuzda, P. Matsudaira, B.A. Yankner. Generation of $\beta$ amyloid in the secretory pathway in neuronal and nonneuronal cells. Proc. Natl. Acad. Sci. USA, 90 (1993), pp. 2092-2096

6B.J. Cummings, E. Head, W. Ruehl, W. Milgram, C.W. Cotman. The canine as an animal model of human aging and dementia. Neurobiol. Aging, 17 (1996), pp. 259-268

7B.J. Cummings, J.H. Su, C.W. Cotman. Neuritic involvement within bFGF immunopositive plaques of Alzheimer's disease. Exp. Neurol., 124 (1993), pp. 315-325

B.J. Cummings, J.H. Su, C.W. Cotman, R. White, M.J. Russell. $\beta$-Amyloid accumulation in aged canine brain: a model of early plaque formation in Alzheimer's disease. Neurobiol. Aging, 14 (1993), pp. 547-560

9B.J. Cummings, J.H. Su, J.W. Geddes, et al. Aggregation of the amyloid precursor protein within degenerating neurons and dystrophic neurites in Alzheimer's disease. Neuroscience, 48 (1992), pp. 763-777

Brain Research, Vol 774, No. 1-2 (November 1997): pg. 35-43. DOI. This article is (C) Elsevier and permission has been granted for this version to appear in e-Publications@Marquette. Elsevier does not grant permission for this article to be further copied/distributed or hosted elsewhere without the express permission from Elsevier. 
10O. Fischer. Miliare Nekrosen mit Drusigen Wucherungen der Neurofibrillen, eine Regelmassige Veranderung der Hirnrinde bei Seniler Demenz. Monatsschr. Psychiatr. Neurol., 22 (1907), pp. 361-372

11S.C. Fuller. A study of the miliary plaques found in brains of the aged. Am. J. Insanity, 68 (1911), pp. 147-219

12DD. Goldgaber, A.I. Schwarzman, R. Bhasin, et al. Sequestration of amyloid beta-peptide. Ann. NY Acad. Sci., 695 (1993), pp. 139-143

13 S.G. Greenberg, P. Davies. A preparation of Alzheimer paired helical filaments that displays distinct tau proteins by polyacrylamide gel electrophoresis. Proc. Natl. Acad. Sci. USA, 87 (1990), pp. 5827-5831

$\underline{14}$ E. Harlow, D. Lane, Antibodies. A Laboratory Manual, Cold Spring Harbor Laboratory, NY, 1988, pp. 298-300.

$\underline{15}$ E. Head, R. Mehta, J. Hartley, M. Kameka, B.J . Cummings, C.W. Cotman, W.W. Ruchl, N.W. Milgram. Spatial learning and memory as a function of age in the dog. Behav. Neurosci., 109 (1995), pp. 851-858

${ }_{16}$ P.R. Hof, C. Bouras, L. Buee, A. Delacourte, D.P. Perl, J.H. Morrison. Differential distribution of neurofibrillary tangles in the cerebral cortex of dementia pugilistica and Alzheimer's disease cases. Acta Neuropathol. (Berl.), 85 (1992), pp. 23-30

${ }^{17}$ N. Ichihara, J. Wu, D.H. Chui, K. Yamazaki, T. Wakabayashi, T. Kikuchi. Axonal degeneration promotes abnormal accumulation of amyloid $\beta$ protein in ascending gracile tract of gracile axonal dystrophy (GAD) mouse. Brain Res., 695 (1995), pp. 173-178

18R.W. Kirk, Current Veterinary Therapy VII: Small Animal Practice, W.B. Saunders, Philadelphia, PA, 1980.

$\underline{19}$ E.H. Koo, S.S. Sisodia, D.R. Archer, L.J. Martin, A. Weidemann, K. Beyreuther, P. Fisher, C.L. Masters, D.L. Price. Precursor of amyloid protein in Alzheimer disease undergoes fast anterograde axonal transport. Proc. Natl. Acad. Sci. USA, 87 (1990), pp. 1561-1565

20D.A. Lewis, M.J. Campbell, R.D. Terry, J.H. Morrison. Laminar and regional distributions of neurofibrillary tangles and neuritic plaques in Alzheimer's disease: a quantitative study of visual and auditory cortices. J. Neurosci., 7 (1987), pp. 1799-1808

${ }^{21}$ A. Migheli, A. Attanasio, T. Pezzulo, F. Gullotta, M.T. Giordana, D. Schiffer. Age-related ubiquitin deposits in dystrophic neurites: an immunoelectron microscopic study. Neuropathol. Appl. Neurobiol., 18 (1992), pp. 3-11

$\underline{22}$ N.W. Milgram, E. Head, E. Weiner, E. Thomas. Cognitive functions and aging in the dog: acquisition of nonspatial visual tasks. Behav. Neurosci., 108 (1994), pp. 57-68

233.M. Nieto, F. Mora. Active microglia, sick astroglia and Alzheimer type dementias. Neuroreport, 5 (1994), pp. 375-380

Brain Research, Vol 774, No. 1-2 (November 1997): pg. 35-43. DOI. This article is @ Elsevier and permission has been granted for this version to appear in e-Publications@Marquette. Elsevier does not grant permission for this article to be further copied/distributed or hosted elsewhere without the express permission from Elsevier. 
NOT THE PUBLISHED VERSION; this is the author's final, peer-reviewed manuscript. The published version may be accessed by following the link in the citation at the bottom of the page.

${ }^{24}$ R.C. Pearson, M.M. Esiri, R.W. Hiorns, G.K. Wilcock, T.P. Powell. Anatomical correlates of the distribution of the pathological changes in the neocortex in Alzheimer disease. Proc. Natl. Acad. Sci. USA, 82 (1985), pp. 4531-4534

25 J.L. Price, P.B. Davis, J.C. Morris, D.L. White. The distribution of tangles, plaques and related immunohistochemical markers in healthy aging and Alzheimer's disease. Neurobiol. Aging, 12 (1991), pp. 295-312

26E. Redlich. Ueber Miliare Sklerose der Hirnrinde bein Seniler Atrophie. Jahrbucher Psychiatr. Neurol., 17 (1898), pp. 208-216

27]. Rogers, J.H. Morrison. Quantitative morphology and regional and laminar distributions of senile plaques in Alzheimer's disease. J. Neurosci., 5 (1985), pp. 2801-2808

${ }^{28}$ A.E. Roher, J.D. Lowenson, S. Clarke, C. Wolkow, R. Wang, R.J . Cotter, I.M. Reardon, H.A. Zurcher-Neely, R.L. Heinrikson, M.J. Ball, B.D.

Greenberg. Structural alterations in the peptide backbone of $\beta$-Amyloid core protein may account for its deposition and stability in Alzheimer's disease. J. Biol. Chem., 268 (1993), pp. 3072-3083

${ }_{29}^{29}$. Seubert, P.C. Vigo, F. Esch, et al. Isolation and quantification of soluble Alzheimer's beta-peptide from biological fluids. Nature, 359 (1992), pp. 325-327

${ }^{30}$ B.E. Tomlinson, G. Blessed, M. Roth. Observations on the brains of nondemented old people. J. Neurol. Sci., 7 (1968), pp. 331-356

31B.E. Tomlinson, G. Blessed, M. Roth. Observations on the brains of demented old people. J. Neurol. Sci., 11 (1970), pp. 205-242

32P.C. Vigo, D. Lee, P. Keim, I. Lieberburg, D.B. Schenk. Characterization of beta-amyloid peptide from human cerebrospinal fluid. J. Neurochem., 61 (1993), pp. 1965-1968

$\underline{33} \mathrm{H}$. Yamaguchi, K. Ishiguro, S. Sugihara, et al. Presence of apolipoprotein E on extracellular neurofibrillary tangles and on meningeal blood vessels precedes the Alzheimer beta-amyloid deposition. Acta Neuropathol. (Berl.), 88 (1994), pp. 413-419

${ }^{34}$ A.J . Yang, M. Knauer, D.A. Burdick, C. Glabe. Intracellular A beta 1-42 aggregates stimulate the accumulation of stable, insoluble amyloidogenic fragments of the amyloid precursor protein in transfected cells. J. Biol. Chem., 270 (1995), pp. 14786-14792

Brain Research, Vol 774, No. 1-2 (November 1997): pg. 35-43. DOI. This article is @ Elsevier and permission has been granted for this version to appear in e-Publications@Marquette. Elsevier does not grant permission for this article to be further copied/distributed or hosted elsewhere without the express permission from Elsevier. 